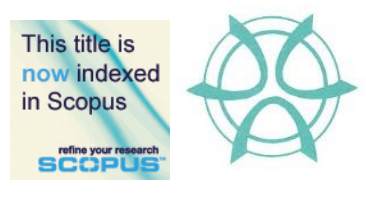

PLANNING MALAYSIA:

Journal of the Malaysian Institute of Planners

VOLUME 16 ISSUE 3 (2018) Page 109 - 120

\title{
ASSESSING URBAN PUBLIC TRANSPORTATION INSTITUTIONAL FRAMEWORK IN KLANG VALLEY
}

\author{
Noor Ashikin Abd Rahman', Yusfida Ayu Abdullah², Na'asah Nasrudin³ , \& \\ Zaharah Mohd Yusoff ${ }^{4}$ \\ ${ }^{1,2,3,4}$ Faculty of Architecture, Planning and Surveying \\ UNIVERSITI TEKNOLOGI MARA, MALAYSIA
}

\begin{abstract}
This study has a special interest in urban public transportation institutional framework in the Klang Valley, Malaysia. The notions for the topic were developed from issues regarding institutional framework in delivering urban public transportation. Although the current urban public transport in Klang Valley has improved, there are still issues concerning the institutional framework. To date, there is no single regulator or agency with the express and overriding responsibilities for strategic management of the public transport system in Klang Valley. The purpose of this study is therefore to assess the current urban public transportation institutional and governance framework especially towards urban mobility. To achieve this, the study employs the content analysis and case study method, using the purposive sampling approach for expert interviews in gaining the data from participants of related agencies. It examines the importance of public transportation frameworks and present status of current transport development, as well as the roles of urban transportation agencies involved in delivering urban public transport. Results demonstrated that urban public transportation is delivered through multiple agencies with separate roles, not counting the inconsistency of various policies. Hence, the expectation of this study is to suggest practical approaches to improve the current institutional framework of urban public transportation.
\end{abstract}

Keywords: urban public transportation, institutional framework, governance, Klang Valley 
Noor Ashikin Abd Rahman, Yusfida Ayu Abdullah, Na'asah Nasrudin, \& Zaharah Mohd Yusoff

Assessing Urban Public Transportation Institutional Framework in Klang Valley

\section{INTRODUCTION}

Issues regarding urban public transportation in Malaysia as reported by many academic researchers, news, agencies and experts in the field have remain as one of the national concerns although the country is heading to becoming a welldeveloped country by 2020 . Trends in urban transportation have constantly changed over the years. Urban dwellers in developing countries require and demand mobility and accessibility at the same rates of growth of these urban areas. Often, this demand is accommodated by the increased number of private vehicles. The traffic issues are always associated with private vehicles especially in developing city such as the Federal Territory of Kuala Lumpur. Development of a country is closely linked with the transportation system facilities and it will have a positive impact on the economic growth and social fabric of a country.

An efficient and a comprehensive network transport system between cities is needed in strengthening the focal points of trade and human. The public perception of the existing public transport system in Malaysia has been declining over the years. The challenges in transforming the public transport system into the mode of choice are not limited in increasing infrastructure and its capacity. The integrated and comprehensive approach is required as it is also about improving the regulatory framework, planning structure and the level of services delivered (Abdul Aziz \& Mohd Amin, 2012).

A city like Kuala Lumpur (KL) within the Klang Valley would easily be communicated if the traffic flow ran smoothly and orderly with integration between the public transport systems, and when planning is carried out in accordance with the criteria and guidelines of the existing planning structure (Abd. Rahman \& Abdullah, 2016). Cities should be able to provide an efficient urban structure and equitable society which all members can easily gain access to all amenities and enjoy the maximum benefits of city life.

Klang Valley residents, particularly in the City of Kuala Lumpur are expected to reach 10 million people by 2020 when it had attained the status of Greater Kuala Lumpur. This will lead to an increased in vehicle ownership, intensified mobility and accessibility, which potentially result in high urban traffic congestion, fostering travel time, higher demands for parking spaces in city centre and multiplied rates of injury as well as fatality which will all beget to environmental degradation. Hence, many public transport advocators in developing cities would argue for the switch of private vehicles to public transportation to overcome these negative effects of transportation (Economic Planning Unit, 2014).

The context of this paper focuses on the deliverable of public transport management and also on institutional and governance framework for urban public transportation. Institutional and governance framework and their related networks are critical as to how well urban transport infrastructure and services especially on public transport are planned, appraised, delivered and operated. 
PLANNING MALAYSIA

Journal of the Malaysia Institute of Planners (2018)

Well-functioning institutions are essential in creating and maintaining good quality infrastructure and services for urban mobility. The integration of land use and transport planning is also necessary to ensure the efficacy of urban mobility systems (UN Habitat, 2013).

Since transportation infrastructure crosses municipal boundaries, therefore cooperation among federal, state and local government is very important. The public transport planning and enforcement framework are seen fragmented because they involve multiple authorities. All authorities have delivered their large mandates but there is none single regulator or agency with the express and overriding responsibilities for strategic management of the public transport system (Suruhanjaya Pengangkutan Awam Darat, 2012). Currently, there is no single coordinating body for the Klang Valley region or metropolitan region which includes Kuala Lumpur, Shah Alam, Petaling Jaya, Subang Jaya, Ampang, Selayang and Kajang even though the responsibility for transport is shared among various agencies directly or indirectly.

\section{METHODOLOGY}

This study focuses on reviewing the concept and practice of urban public transportation management and analysis of the urban public transport institutional framework and governance using content analysis approach. Additionally, it applies case study method to investigate the existing institutional framework for urban transportation and policy, including its delivery and management of public transportation by the government and related agencies in the Klang Valley.

Klang Valley was chosen as a case study because it comprises several cities functioning as satellite city to the capital of Malaysia, Kuala Lumpur (KL). The cities include Shah Alam, Petaling Jaya, Subang Jaya, Ampang, Selayang and Kajang. Klang Valley was also selected because of the challenges it faces to accommodate additional private cars every year with the total cumulative of motor vehicles about $91 \%$ of public cars, $1 \%$ of public transport and another $8 \%$ of others (Ministry of Works, 2014). The upsurge of motor vehicles is faster than the population growth. It was highlighted that Klang Valley requires a suitable and complete network system which provides road accessibility and high quality public transportation service in major routes that provides a seamless transportation system (Abd. Rahman \& Abdullah, 2016). In addition, the public transport modal share remains low at $17 \%$ as compared to the target of $25 \%$ in 2014 (Ministry of Transport, 2014). In supporting the sustainable transport system, these criteria should be emphasised. Hence, the institutional framework structure which encompasses the administration at the federal, state and local levels is crucial in public transport development.

Further to that, the general process of this research contains five stages including preliminary study, literature review, data collection, analysis and findings and recommendation (Figure 1). This research also engaged expert 
Noor Ashikin Abd Rahman, Yusfida Ayu Abdullah, Na'asah Nasrudin, \& Zaharah Mohd Yusoff Assessing Urban Public Transportation Institutional Framework in Klang Valley

interviews involving six (6) agencies which are the core agencies in the formation of policy, planning, regulation, implementation and enforcement. The expert interviews exercised the purposive sampling method in selecting the individuals for interviews that are particularly knowledgeable and experienced as participants for the study (Palinkas et al., 2016). Using structured interview, the interview questions were developed consisting of five (5) distinctive parts: Section ABackground of Interviewee; Section B- Background of Agency; Section CAdministration and Policies; Section D- Issues and Problems; and Section ESuggestion. The data obtained from the interviews were analysed by using IBM SPSS Version 21, as well as descriptive statistics namely percentage and used of mixed method analysis by collecting and analysing both quantitative (closedended) and qualitative (open-ended).

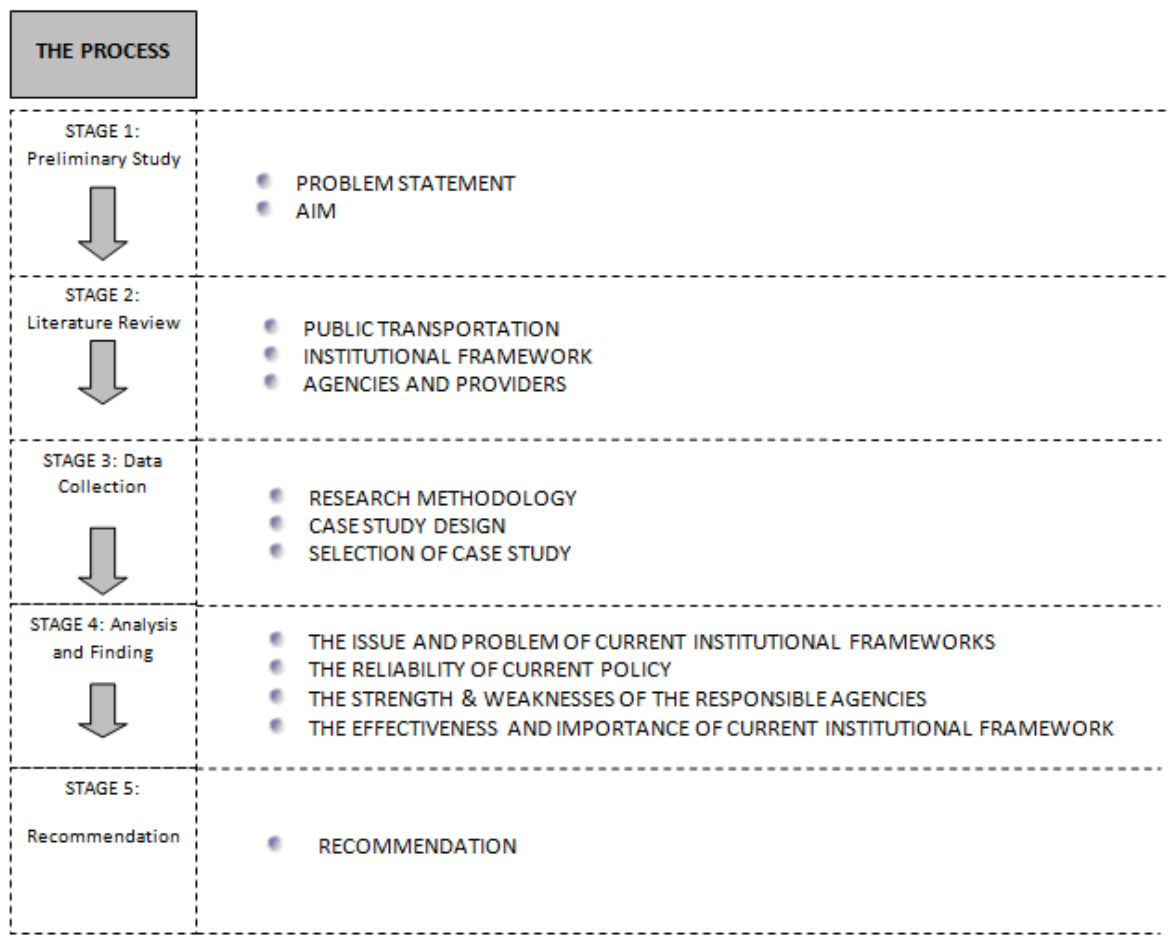

Figure 1: Approach to case study method

\section{DESCRIPTIVE SUMMARY}

Urbanization is a key driver of cities' success, but growing challenges in urban mobility threaten to dampen the benefits of cities. In 1985, 51\% of Malaysian lived in cities but this had increased to $75 \%$ in 2015. Rapid urbanization boosted productivity and access to economic opportunities, raised income and reduced 
PLANNING MALAYSIA

poverty, but at same time have increased road congestions in Malaysian cities, including insufficient public transit and dissatisfaction of public transport provision (Sander, 2015).

Over the past few years, urban development receives pressure from the economic growth and increasing population growth. Public transport is one of the main problems of the people in cities because it has direct impacts on their daily lives. This is corroborated by the number of articles and news about public transportation published in the media such as Malaysian Digest (2015), TallyPress.Com (2016), The Star (2017) and many more (Abd. Rahman \& Abdullah, 2016). A critical issue particularly in the Klang Valley area is the overloading of inward-outwards traffic flow of central Kuala Lumpur that demands for the need of efficient and effective public transport service supply. More than 4 million passengers per week use public transport in Kuala Lumpur and the Klang Valley. It is a concerning pressure towards public transport services and indicates the need for better services (Jaafar, Ponrahono, Bachok, Ibrahim, \& Osman, 2014).

Malaysia is also experiencing rapid development in order to achieve Vision 2020, thus, an efficient transportation system is needed to enhance the productivity and encourages economic activities, thereby increasing the national output and competitiveness (Economic Planning Unit, 2015). Kuala Lumpur itself is a booming city facing immense challenges in trying to accommodate additional private cars every year and the increased motor vehicles are faster than the population growth (Economic Planning Unit, 2014). The city struggles with air pollution and traffic congestion thus reduces the Quality of Good Life (McKinsey \& Company, 2013). It is just not enough to rely on the factors of convenience to encourage the behaviour of using public transport. Individuals, however, still prefer to purchase private car instead of using public transport (Public Transport User Associations, 2010). Public were seen as reluctant of being in a crowded train with strangers (Department for Transport, 2011). It is for these reasons that the policy makers should learn to understand the unique needs of the general public especially in terms of their dependency on private vehicles before committing to new major projects related to transportation.

Public transportation is, therefore, a cornerstone of a nation's economy which provides a transit medium for daily mobility and the link between the people and their jobs, education and entertainment. Service coverage, travel time, reliability, park and ride facilities, comfort and safety are among the determining factors towards encouraging public transportation as a mode of choice (Land Transport Authority, 2014). One of the main causes of traffic congestions in KL is the substantial number of private vehicles with only a single occupant. This happens because of the weakness of public transport system and the problem is generally caused by the lack of coordination between agencies and the lack of integration of public transport services (Abd. Rahman \& Abdullah, 2016). 
Noor Ashikin Abd Rahman, Yusfida Ayu Abdullah, Na'asah Nasrudin, \& Zaharah Mohd Yusoff

Assessing Urban Public Transportation Institutional Framework in Klang Valley

Many agencies that influence or regulate land use have little or no responsibility for mobility policies. The result is a serious institutional land use and transportation disconnection that prevents integrative actions especially in Klang Valley where urban mobility is weak (UN Habitat, 2013). Looking at the Malaysian Government Transformation Programme's (GTP) strategy, the ratio of private and public transport is still below the target with only $12 \%$ in 2014 and the government is striving to increase it to $25 \%$, targeting the public transportation as the preferable mode of urban transport (Economic Planning Unit, 2014). The government, with the cooperation of the public, can resolve these issues by improving the driving behaviour, frequencies of public transport services and intensities of buses plying the roads of KL.

\section{RESULTS AND DISCUSSION}

The role of institutions in urban public transport is very crucial because cities need transport planning, provision, management and monitoring aspects. The government should provide the enabling frameworks, policies and finances. Not least, urban transport governance is very challenging at various levels; capacity, authority, finances, coordination and so on (Ministry of Urban Development, 2015). Institutions are a set of norms, values and beliefs that have been formed to ensure that targets are achieved while framework is the linkage that supports two or more sub-systems ensuring the easy flow of information or data from one subsystem to another (Wapwera, Mallo, \& Jiriko, 2015). Institutions are broadly defined as systems of rules (roles, responsibilities, planning, regulation, service, provision, monitoring and financing) (Figure 2), either formal or informal and those rules define the boundaries of any institution (Ministry of Urban Development, 2015).

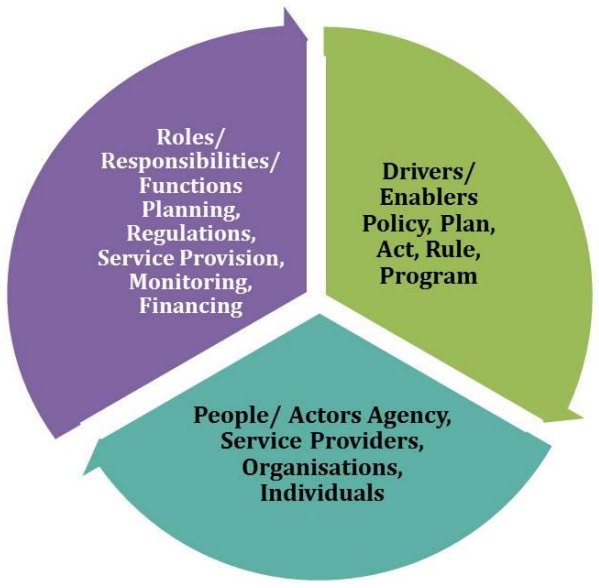

Figure 2: Institutional framework 
PLANNING MALAYSIA

Journal of the Malaysia Institute of Planners (2018)

At present, a range of public and private institutions have their own responsibilities for transportation in the Klang Valley. According to the Land Public Transport Commission (2012), there are many agencies focusing on public transport in Malaysia such as the Prime Minister's Office, Economic Planning Unit (EPU), Ministry of Finance (MoF), Ministry of Housing, Urban Wellbeing and Local Government, Ministry of Transport (MoT), Ministry of Works (MoW), Ministry of Federal Territories, Ministry of Natural Resources and Environment, Ministry of Home Affairs and also the Land Public Transport Commission. These agencies are accountable and form part of the institutional framework for urban public transport in Malaysia whether directly or indirectly.

For now, no single government agency has the authority to plan and deliver solutions for urban mobility across all relevant dimensions (public and private transport mode) and level of government, and administrative geographical boundaries (especially among local authorities and states). The Land Public Transport Commission or known as the Suruhanjaya Pengangkutan Awam Darat (SPAD) has been given the jurisdiction over land public transport only and not including private (car-based) transport planning, which at the national level (federal level) is under the jurisdiction of Ministry of Works. In practice, the overall transport planning between private and public transport is formulated and delivered with limited coordination between agencies (Sander, 2015).

Based on the study, it was apparent that urban public transportation in Klang Valley faces many disputes in relation to its institutional framework, such as discussed below.

\section{Institutional Coordination between Agencies for Urban Public Transportation}

The issue of public transportation is related to the complexity of land use and lack of holistic approach in development and planning strategies. Furthermore, lack of comprehensive planning is the key factor which creates connectivity gaps, thus rendering the Land Public Transport (LPT) services as inefficient and not userfriendly. A cohesive effort between the Federal, States and Local Authorities needs to be established and clearly defined roles and responsibilities are critical to ensure a seamless system is put in place (Abdul Aziz \& Mohd Amin, 2012).

The development has led to institutional conflicts in several areas especially enforcement, infrastructure provision and use, policy formulation and coordination. Problems of complexity, planning, implementation and enforcement should be viewed seriously because there are different ministries and agencies at the federal and local levels involved in various aspects of public transport in the Klang Valley. It is necessary to create a central responsibility for policy planning and regulatory oversight to achieve successful initiatives (Oni, Okanlawon, \& Asenime, 2006). Furthermore, the four (4) thrusts should be carried out especially in ensuring that the transportation efficiency such as 
Noor Ashikin Abd Rahman, Yusfida Ayu Abdullah, Na'asah Nasrudin, \& Zaharah Mohd Yusoff

Assessing Urban Public Transportation Institutional Framework in Klang Valley

collaborative planning and governance, regulatory strengthening, service quality and excellence and also infrastructure and capacity (Abdul Aziz \& Mohd Amin, 2012).

Based on the expert interviews, it was discovered that the lack of foresight on behalf of the government has resulted in a situation where Klang Valley endures high level of car ownership but low level of public transportation usage. A poor public transportation system will only force more people to not choose public transport, more so if they have access to private vehicles. Public transportation in semi-urban and rural areas has suffered the most from these disastrous policies. Worse still is the fact that local authorities have been witnessing this deterioration with the lack of finances and most importantly the jurisdiction to arrest the situation. The poor public transport system costs the Klang Valley people too much.

From the analysis, $80 \%$ of the interviewees suggested that the government should focus on coordination between relevant agencies because separate efforts will cause a mismatch and redundancy of services and development. Furthermore, serving the convenient and price point of the public transport is the most important part to shift the culture of high usage of private transport into public transport. According to the World Bank's report, the rates at which roads were being built were unable to match with the expansion rates of car possession. Furthermore, the issue of traffic congestion in Malaysia's cities especially in Kuala Lumpur and Selangor is a result of insufficient public transit as an alternative to car use along with public satisfaction towards public transport are low. These threaten the achievement of public transport usage for Malaysian (Sander, 2015).

The task in transforming public transport in the Klang Valley was led by SPAD in coordination with various agencies. However, lack of coordination among agencies in planning and implementation of various policies and initiatives had resulted in inefficient use of public transport. Although there is an established public transport committee yet there is still a lack of efficacy in carrying out public transport improvements plan. Overseen by different agencies, urban transport planning is not integrated across modes and administrative boundaries. Transport planning does not span to Greater Kuala Lumpur or Klang Valley conurbation, which is often defined differently by different agencies. At the federal level, the Ministry of Transport, Ministry of Works and SPAD are responsible for planning and delivering urban transport (private and public transport) especially at the city level. But in Vancoucer, urban transport planning is done at the metropolitan level (Sander, 2015).

\section{Issues of Policy Implementation for Urban Transportation}

Urbanization boosted the economic opportunity especially for big cities and changes the style of development. Road congestions are mainly caused by high 
motorization rates and this was proven by the Ministry or Works that car ownership ascends higher annually (Ministry of Works, 2014). The National Automotive Policy does not match with the Eleventh Malaysia Plan (RMK-11), which The National Land Public Transport Master Plan 2012-2030 has set to improve the public transport modal share from $16 \%$ to $40 \%$ in 2030 . Based on the analysis, $60 \%$ of the interviewees agreed that relevant agencies should implement the policies formulated and what is needed is that all public transport players commit in delivering good services to the public with continuous improvement and engagement so that relevant agency such as SPAD can start playing a bigger role for policy planning and improvement (Abd Rahman, 2018).

\section{RECOMMENDATIONS}

With regards to the results of the analysis, to improve the current institutional framework and transform the planning and delivery or urban transport in the Klang Valley, the government may consider prioritizing the initiatives proposed below.

Establishment of Transport Agency at Metropolitan Level or Regional Level Successful mobility in cities starts at the very top of the policy-making chain. Government should recognise the importance of urban mobility issues nationally and ensure that they are high up on the policy agenda. It is essential to have a national legal and regulatory framework of public transport to become more viable and stable. Clear roles and responsibilities need to be defined for each stakeholder in the mobility supply chain in delivering real results on the ground. A proposed institutional framework for urban public transportation in Klang Valley is illustrated below (Figure 3):

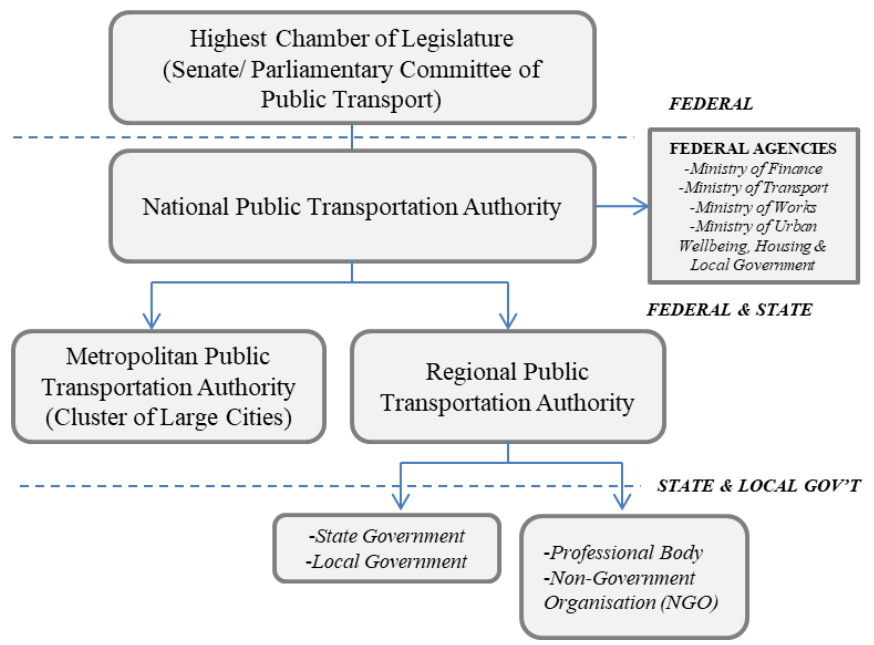

Figure 3: Proposed new institutional framework 
Noor Ashikin Abd Rahman, Yusfida Ayu Abdullah, Na'asah Nasrudin, \& Zaharah Mohd Yusoff

Assessing Urban Public Transportation Institutional Framework in Klang Valley

Overseen by different agencies, urban public transport is not integrated across modes and administration boundaries. Agencies such as the Ministry of Transport, Ministry of Works and SPAD are the federal level agencies responsible for planning and delivering urban transport at the city level but not in a metropolitan/regional level. This establishment of a new institutional framework can integrate approach towards the policy, planning and delivery of urban transport across different modes and across the administration boundaries.

\section{Policy Alignment and Implementation}

Government or agency should emphasized to align all relevant development policies from Vision 2020, National Physical Plan 3 (NPP3), National Urbanisation Policy, Land Public Transport Master Plan, Eleventh Malaysia Plan and also development plans at every relevant city to promote an efficient and effective land public transport. Hence, if we want to achieve a $40 \%$ modal share for public transport in urban areas especially in the Klang Valley, the policy makers should therefore focus on major policies. This initiative should consider the transportation infrastructure policy by giving the priority to public transport development and also the land use policy by adopting compact, connected and coordinated cities, in addition to adapting the Transit Oriented Development (TOD) and allowing a maximum plot ratio up to 1:8 for every development that implemented this policy especially in Selangor (JPBD Selangor, 2016).

Based on the analysis, in delivering good public transport services to the public, it should refer to supply and demand system. The government have not encouraged the public enough in using the public transport. It should, at the same time implements policies to support the initiative such as increasing new car price, reconsider when building new road or highways and provide tax exemption for urban public transport (Abd. Rahman, 2018). Furthermore, the government must align all policies to promote public transport incentives to discourage the usage of private transport in congested areas like Klang Valley. By implementing these policies, it will help Malaysia to transform its public transport system and achieve the vision of "Public Transport as Rakyat Choice of Mobility' through physically well connected, affordable and accessible, high level services, convenience, safe, secure, reliable and sufficient information (Suruhanjaya Pengangkutan Awam Darat, 2012).

\section{CONCLUSION}

A region like Klang Valley would easily be communicated if the traffic flow ran smoothly and orderly, and when there is integration between the public transport systems. Likewise, this can be achieved through a good public transport planning system and policy implementation through an integrated and across mode and administrative boundaries. Cities should be able to provide an efficient urban structure and equitable society which all members can easily gain access to all 
the amenities and enjoy the maximum benefits of city life. Moreover, the implementation of effective public transport system is the key solution in improving people mobility and also to counter the major problem of urban public transportation in Klang Valley. With the right regulatory and institutional framework in place, Klang Valley will have the power to define how they can encourage the people to use public transport and also achieve developing country with efficient and affordable transportation network towards 2020.

Note: During the study, SPAD was still lawful as the responsible commission for land public transport. However, the newly elected government, has announced in June 2018 that SPAD is to be disbanded and replaced by the Agensi Pengangkutan Awam Darat (APAD) or also known as the Land Public Transport Agency. APAD will therefore be responsible in delivering the public transport policies in the country. It is also will be responsible for the planning and development of public transport especially for Mass Rapid Transport (MRT) and Light Rail Transit (LRT). To avoid any conflicts of duties, APAD will have a separate role from the Road Transport Department Malaysia or Jabatan Pengangkutan Jalan (JPJ). JPJ itself will function accordingly based on the Land Public Transport Act 2010. At this point (August 2018), the restructuring of SPAD is still ongoing.

\section{ACKNOWLEDGEMENT}

The authors would like to thank the Public Service Department of Malaysia for funding the research, the Universiti Teknologi MARA (UiTM) and the Centre of Postgraduate Studies FSPU, UiTM for the provision of support facilities. A special thank goes to all the participants from the government departments, organisations and individuals who have contributed to this study.

\section{REFERENCES}

Abd. Rahman, N. A. (2018). Draft of analysis for urban public transportation institutional framework in Malaysia [Unpublished].

Abd. Rahman, N.A., \& Abdullah, Y. A. (2016). Theorizing the concept of urban public transportation institutional framework in Malaysia. $4^{\text {th }}$ International Building Conference (IBCC 2016). March 7-8, 2016, Kuala Lumpur, Malaysia.

Abdul Aziz, A., \& Mohd Amin, N. F. (2012). Transforming the land public transport system in Malaysia. Sharing Urban Transport Solutions, 30.

Department for Transport (2011). Travel training: Good practice guidance. London: Author.

Economic Planning Unit (2014). Government transformation programme: Annual report 2014. Malaysia: Government of Malaysia.

Economic Planning Unit (2015). Eleventh Malaysia plan (RMK-11). Malaysia: Government of Malaysia.

Jaafar, S., Ponrahono, Z., Bachok, S., Ibrahim, M., \& Osman, M. M. (2014). Urban public transportation cycle and sustainability challenges in Malaysia. International Islamic University Malaysia Research, Invention and Innovation Exhibition: IIUM.

Jabatan Perancangan Bandar dan Desa Negeri Selangor [JPBD Selangor] (2016). Dasar perancangan pembangunan berorientasikan transit negeri Selangor. Selangor, Malaysia: Author. 
Noor Ashikin Abd Rahman, Yusfida Ayu Abdullah, Na'asah Nasrudin, \& Zaharah Mohd Yusoff

Assessing Urban Public Transportation Institutional Framework in Klang Valley

Land Public Transport Commission (2012). Greater KL/Klang Valley - Land public transport master plan. Kuala Lumpur: Government of Malaysia.

Land Transport Authority (2014). Land Transport Authority annual report. Singapore: Author.

Malaysian Digest (2015, April 3). The problem with Malaysia's public transport. Is change on the horizon? Retrieved from http://www.malaysiandigest.com/news/548349-the-problem-with-malaysia-spublic-transport-is-change-on-the-horizon.html.

McKinsey \& Company (2013). How to make a city great. Retrieved from https://www.mckinsey.com/featured-insights/urbanization/how-to-make-a-citygreat

Ministry of Transport (2014). Strategy paper - Providing seamless transportation. Malaysia: Government of Malaysia.

Ministry of Urban Development (2015). Institutional development in urban transport. India: Government of India.

Ministry of Works (2014). Road traffic volume 2014. Malaysia: Government of Malaysia.

Oni, S. I, Okanlawon, K. R., \& Asenime, C. O. (2006). Institutional framework for the transformation of transport administration in Metropolitan Lagos. In R. Anifowose, \& T. Babawale (Eds.), An agenda for a new Nigeria: The imperative of transformation (pp. 421-437). Lagos, Nigeria: Concept Publications Limited.

Palinkas, L. A., Horwitz, S. M., Green, C. A., Wisdom, J. P., Duan, N., \& Hoagwood, K. (2015). Purposeful sampling for qualitative data collection and analysis in mixed method implementation research. Administration and Policy in Mental Health, 42(5), 533-544.

Public Transport User Associations (2010). Public transportation. Available at https://www.ptua.org.au/2010/.

Sander, F. G. (2015). Malaysia economic monitor June 2015: Transforming urban transport. Thailand: The World Bank.

Suruhanjaya Pengangkutan Awam Darat (2012). National land public transport master plan. Kuala Lumpur: Government of Malaysia.

TallyPress.com (2016, January 6). 8 Reasons why Malaysians are extremely frustrated with our transportation system. Retrieved from https://tallypress.com/fun/8reasons-why-malaysians-are-extremely-frustrated-with-our-transportationsystem.

The Star (2017, April 1). Awareness is key to public transport take-off. Retrieved from https://www.thestar.com.my/business/business-news/2017/04/01/ awareness-iskey-to-public-transport-takeoff/

UN Habitat (2013). Planning and design for sustainable urban mobility: Global repost on human settlement 2013. Kenya: Author.

Wapwera, S. D., Mallo, D. M., \& Jiriko, G. J. (2015). Institutional framework and constraints in the urban and regional planning system in Jos Metropolis, Nigeria. Journal of Geography, 8(10), 244-260. 